\title{
The Impact of Interest Rate Marketization on Commercial Banks
}

\section{Yulin $\mathrm{He}^{*}$}

China Jiliang University, Zhejiang 310018, China. E-mail: 2167077606@qq.com

\begin{abstract}
Interest rate marketization means that the interest rate level of financial institutions operating and financing in the money market is determined by market supply and demand. It includes interest rate determination, interest rate transmission, interest rate structure and marketization of interest rate management. At present, there are still many deficiencies and defects in the traditional interest rate management system. The reform of interest rate marketization is the focus of China's financial system reform. Therefore, we should not only be brave in innovation, but also carefully study and analyze. In the analysis process, this paper focuses on the impact of interest rate marketization on commercial banks, and puts forward some countermeasures.
\end{abstract}

Keywords: Interest Rate Marketization; Commercial Banks; Countermeasures

\section{The meaning and background of interest rate marketization}

Interest rate marketization is an important part of China's financial reform, and also an important aspect of the price marketization of production factors.

\subsection{The meaning of interest rate marketization}

Market interest rate, in a simple way, is to give the decision-making power of interest rate to financial institutions. The financial institutions themselves will adjust the interest rate level according to the capital situation and the judgment of the financial market trend, and finally form a market interest rate system and interest rate form based on the benchmark interest rate of the central bank, with the money market interest rate as the intermediary, and the market supply and demand determining the deposit and loan interest rates of financial institutions mechanism.

\subsection{The background of interest rate marketization}

China's interest rate marketization has always been the focus topic of policy and academic circles. The party and the state attach great importance to the reform of interest rate marketization in China. In 2003, the report of the 16th National Congress of the Communist Party of China proposed: steadily promote the reform of interest rate marketization and optimize the allocation of financial resources. "Decision of the Central Committee of the Communist Party of China on several issues concerning the improvement of the socialist market economic system" on the third plenary session of the 16th Central Committee of the Communist Party of China further specified that "steadily promote the marketization of interest rates, establish and improve the formation mechanism of interest rates determined by market supply and demand, and guide market interest rates through the use of monetary policy tools by the central bank." In Oct o ber 2004, the people's Bank of China decided to allow the RMB deposit interest rate of financial institutions to float 
downward. Therefore, the only restriction on deposit interest rate is actually "upper limit control". After the 18th National Congress of the Communist Party of China, interest rate liberalization reform has once again become the focus of social concern ${ }^{[1]}$.

\subsection{Disadvantages of traditional interest rate management system}

There are two main types of interest rate management system, one is interest rate control, the other is interest rate marketization, and China's interest rate management system is mainly interest rate control type. This kind of interest rate control leads to the low overall level of interest rate, including the unreasonable interest rate structure, the imperfect differential interest rate policy, and the imbalance between the supply and demand of social loan funds.

(1) Interest rate control generally includes the lowering of interest rate level and credit rationing system, which destroys the price regulation level of interest rate and is easy to breed corruption.

(2) The government sets a lower interest rate on the nominal interest rate, which will stimulate investment growth on the one hand and reduce household savings on the other. With the decrease of savings, the sources of consumption will also be reduced, and the expansion of investment scale will certainly be affected, which will reduce the expansion effect of investment caused by low interest policy to a certain extent. Moreover, a considerable part of the reduced savings will enter the consumption field, which will lead to excessive demand for consumer goods, thus raise prices and easily lead to inflation.

\subsection{The promotion of Internet finance to interest rate marketization}

At present, China's Internet finance can be divided into four categories: network financing, network investment, third-party payment and network currency. Among them, network financing and network investment have the most direct impact on the interest rate market, and the Internet monetary fund represented by Yu Ebao is the best representative of these two aspects. Yu Ebao has a high and stable rate of return, so many people will choose Yu Ebao for savings de$\operatorname{posit}^{[2]}$.

\section{The impact of interest rate marketization on commercial banks}

The reform of interest rate marketization is the overall trend of the development of the world financial market at present, and also makes China's commercial banks in a new competitive environment. The reform of interest rate marketization will inevitably bring impact on commercial banks, but opportunities and challenges always coexist. As long as commercial banks take active measures to deal with them, they will certainly get opportunities in the challenges and achieve better development of commercial banks.

\subsection{The positive influence of interest rate marketization on commercial banks}

(1) It can promote fair competition among banks and give full play to the autonomy of commercial banks

After the implementation of interest rate marketization, banks will have more independent pricing power, capital prices can more accurately reflect the relationship between supply and demand of funds. Through the analysis and accounting of capital prices and operating costs, we can determine a reasonable interest rate level, reduce interest rate risk, and improve the risk control ability of commercial banks ${ }^{[3]}$. In addition, interest rate liberalization can effectively reduce corruption, and banks can absorb deposits through their own management and comprehensive strength. When making loans, it can also make the price of loans open, make the competition between banks more fair, and improve the transaction efficiency of banks and enterprises.

(2) It is conducive to promote the transformation and structural adjustment of banking business and expand the scope of financial product innovation and intermediary business.

From the international experience, the implementation of interest rate liberalization will change the al business model of banks and the scope of business ${ }^{[4]}$ when banks obtain the right of independent pricing, they will vigorously expand loans for SMEs and consumers to obtain higher returns.

(3) It is helpful to optimize the customer structure and improve the management level of commercial banks 
Before the implementation of interest rate marketization, China has been in the era of artificially low interest rate regulation. The implementation of interest rate regulation can protect and support state-owned enterprises and realize the leap forward development of China's economy.

\subsection{The negative influence of interest rate marketization on commercial banks}

(1) The interest rate of deposit and loan will rise significantly, the interest rate spread may be narrowed, and the profitability of banks mainly engaged in traditional deposit and loan business will decline.

The interest rate marketization makes the deposit and loan spread of commercial banks narrow, and the profitability of banks will be greatly impacted. Before the marketization of interest rate in China, the income source of commercial banks has always been the traditional business; after the marketization of interest rate in China, the commercial banks enjoy the actual control over the interest rate of deposit and loan, which will lead to the intensified competition among commercial banks.

(2) Due to the increase of interest rate fluctuation and the rise of credit risk and liquidity risk, the pricing and risk management ability of banking products will be tested.

The interest rate risk of commercial banks refers to the deviation of profit and loss or market price from the expected value due to the uncertainty of market interest rate. Compared with the period of interest rate regulation, the volatility and uncertainty of market interest rate have a greater impact on banks, which makes China's commercial banks face increased risks ${ }^{[5]}$.

\section{Commercial banks can take the countermeasures of interest rate mar- ketization}

\subsection{Establishing efficient interest rate risk management mechanism}

At present, China's commercial banks are still in the initial stage of asset liability management, and the interest rate risk management mechanism is not developed. The first thing to do is to improve the organizational structure of interest rate risk management, establish a rich information system, and make the capital circulation channel more $\operatorname{smooth}^{[6]}$, further improve the risk management concept and risk management system of banks, and gradually change from passive risk management mode to active and stable risk management mode. At the same time, we should closely follow the trend of interest rates and exchange rates at home and abroad, integrate liquidity management into various businesses, actively introduce interest rate risk hedging technology, actively adjust the balance sheet structure according to the specific situation, and minimize the risk gap by using financial derivatives.

\subsection{Carry out characteristic management}

At present, the phenomenon of homogenization in China's banking industry is very serious. With the deepening of interest rate reform, the business competition among banks is on the rise. If we want to survive in the fierce competition, we must change the old business model and find a suitable model for ourselves which means that commercial banks should make full use of their advantages to form differentiation with other banks' competition ${ }^{[7]}$. Small and medium-sized banks should do a good job in the prediction and management of capital gap, make full use of the capital market, do a good job in liquidity management and reduce the cost of comprehensive liabilities. Large banks should further adjust the traditional business structure and gradually shift credit funds from large manufacturing enterprises with low efficiency to emerging manufacturing and service industries with higher added value ${ }^{[8]}$. In addition, commercial banks can take advantage of a series of advantages, such as shareholder advantages, economic development of the bank's location, financial development characteristics and regional advantages to develop their own core competitiveness, so as to maintain competitive advantages in the market ${ }^{[9]}$.

3.3 Accelerate the development of off balance sheet business, expand the scope of intermediate business and product innovation, and increase the proportion of non-interest income 
Non-interest income mainly depends on off balance sheet business and intermediary business income. While striving to improve the innovation ability of financial products, the advantages of bank assets scale, business network and technical facilities should be brought into full play. At the same time, intermediary business should vigorously increase the proportion of intermediate business in total income, enhance the ability of banks to face risks, and develop the differentiation that can meet different customers. In addition, we should focus on the development of online banking and e-banking, so as to accumulate experience for the transformation to comprehensive operation ${ }^{[10]}$.

\section{Conclusion}

The marketization of interest rate has squeezed the profit margin of the difference between deposits and loans of banks to a certain extent. Compared with the previous years, the loan interest rate has not changed much, but the cost of absorbing funds has increased a lot. The result is the important reason that the valuation level of bank shares has been very low in recent years. However, on the other hand, interest rate marketization promotes the transformation and upgrading of banking business. After the profit margin of the original main business is compressed, banks will take advantage of their basic advantages to develop other businesses, such as intermediary business, such as fund consignment. Generally speaking, the marketization of interest rate promotes the competition between banks to a greater extent, which is conducive to the differentiation of banks. When banks gradually form a characteristic mode, it is undoubtedly conducive to consumers to obtain better service and experience.

\section{References}

1. $\mathrm{Li} \mathrm{H}$. The challenges of interest rate liberalization to banks and the strategies. Studies of International Finance 2015; (2): 12-13.

2. Zhang B. Interest rate liberalization of Internet finance and maturity mismatch of banks (in Chinese). Finance and Economy 2020; (4): 15-17.

3. Xie R. Research on interest rate liberalization in China (in Chinese) [PhD thesis]. Graduate School of Chinese Academy of Social Sciences 2014; 5: 7-10.

4. Lei H. Research on intermediary business development of commercial banks in China under the background interest rate liberalization [PhD thesis]. Southwest University of Finance and Economics 2014; (2): 12-14.

5. Ji Y, Xu J, Zhang B. The impact risk and opportunity of interest rate liberalization (in Chinese). Economic Research Journal 2015; (1): 19-20.

6. Sun X. The liberalization' influence on the effectiveness of China's monetary policy (in Chinese). Modern Business 2020; (9): 4-5.

7. Wang Y. Industrial economic restructuring and countermeasures of commercial banks (in Chinese). Langfang Normal University 2020; (9): 11-13.

8. Zhou Y. Actively promoting market-oriented reform of factor prices (in Chinese). Study Times 2020; (8): 17-18.

9. Tian Z. The risk challenges and countermeasures of interest rate liberalization to commercial banks (in Chinese). National Circulation Economy 2020; (8): 17-18.

10. Wu H. Certificate of deposit interest rate cut (in Chinese). Money Management 2020; (8): 14-15. 